\title{
A Study on Students' Satisfaction of Chinese - Foreign Cooperative Higher Education
}

\author{
Yang LIU, Ying MA, Hui ZHANG* \\ Institute of Higher Education, School of Public Administration, Beihang University, \\ Beijing 100191, P.R. China \\ *Corresponding author
}

Keywords: Students, Satisfaction, Chinese - foreign Cooperative higher education, Instruction.

\begin{abstract}
Students' satisfaction has been becoming a very important way of higher education evaluation in recent decades. In this study, we conducted a sampling survey of the students' satisfaction with the Instruction process of Chinese-foreign cooperative higher education institutions and programs in Beijing area. We divide the instructional process into five dimensions: Classroom Instruction, Evaluation and Feedback, Academic Support, Personal Development, and High- qualityresources Introduction. The results show that the overall satisfaction of students is close to the comparatively satisfactory level, but there is some gap between the participants' expectation and their satisfaction. The students' satisfaction of Instruction is affected by some factors i.e. individual characteristics, program and school characteristics. In addition, the study also found that students from different major and universities are have significant differences in satisfaction in two dimensions of Instruction i.e. the individual development and academic support. The results of this study have some implications for Chinese - foreign Cooperative higher education institutions and programs, and it will be helpful for cooperative programs to improve the quality of Instruction and helpful for students in cooperative programs to develop global perspectives and competences.
\end{abstract}

\section{Background}

Chinese - foreign Cooperation in Running School in higher education institutions is one of the important forms of internationalization of higher education in China. In September 2003, the "Regulations of the People's Republic of China on Sino-foreign Cooperation in Running Schools" stipulate that the state encourages the cooperation of Chinese and foreign educational institutions to introduce foreign quality educational resources. In March 2010, the state issued a "national long-term education reform and development plan Outline 2010-2020", which proposed to encourage schools at all levels to carry out various forms of international exchanges and cooperation. However, are students satisfied with the quality of Instruction in these universities? What factors will affect students' satisfaction with cooperative education? This study tries to answer the important questions.

\section{Literature Review}

We did not find English literature about this topic, so we try to review some studies in Chinese literatures. In China, the scholars basically carry out research on college satisfaction from the individual and the school level. At the individual level, Zhong et al. (2012), Zhao (2010) and Chen(2010) found that there were significant differences in the individual characteristics of university Instruction and service satisfaction among students' age, sex and parental education.

At the school level, according to the study of scholars, including Bao (2014), Zhao (2010), Wu and Luo (2014), Fang and Chen (2010), school type, grade are important factors that affect student satisfaction. According to the study of Bao (2014), the satisfaction of students in research universities is higher than that of other institutions such as public universities, higher vocational colleges, private universities and other institutions, and the satisfaction of students majoring in humanities is higher than that of students in science and engineering. Zhao (2010), Wu and Luo (2014) found that junior students' satisfaction was significantly higher than that of the senior students. 
The participant of this study is students from Chinese and foreign cooperation colleges and programs, and their satisfaction may be related to some other factors: i.e. their parents' overseas experience, the proportion of foreign teachers in the institution or programs, the proportion of foreign Instruction materials, and other factors.

\section{Research Methods}

The data were collected by questionnaire survey. The research group sampled 1,200 students in the cooperative instructions and programs in six universities in Beijing, and we finally collected 752 participants' feedback of questionnaires. The recovery rate was $62.7 \%$. As for the level of institutions, we have sampled two "985" institutions (comprehensive research university), four "211" institutions (research and Instruction university). Based on the literature and the National Students Survey (NSS, 2015) of UK, this study divides the Instruction process into five dimensions: Classroom Instruction, Evaluation and Feedback, Academic Support, Personal Development, and High- quality- resources Introduction. Therefore the questionnaire we designed includes the five dimensions, and each dimension have five to eight items, so totally 31 items were in included in it.

Table1. Descriptive statistics of variables

\begin{tabular}{|c|c|c|c|c|c|c|c|}
\hline Variables & Values & Frequency & $\begin{array}{l}\text { Percentage } \\
\text { (\%) }\end{array}$ & $\begin{array}{l}\text { Minimum } \\
\text { value }\end{array}$ & $\begin{array}{l}\text { Maximum } \\
\text { value }\end{array}$ & $\begin{array}{l}\text { Average } \\
\text { value }\end{array}$ & $\begin{array}{l}\text { Standardd } \\
\text { eviation }\end{array}$ \\
\hline Satisfaction & & 753 & 100 & 1 & 5 & 3.73 & 0.702 \\
\hline Age & & 753 & 100 & 15 & 24 & 19.35 & 1.068 \\
\hline \multirow[t]{2}{*}{ Gender } & Male & 371 & 49.3 & & & & \\
\hline & Female & 382 & 51.7 & & & & \\
\hline \multirow{2}{*}{$\begin{array}{l}\text { Overseas } \\
\text { experience } \\
\text { of parents }\end{array}$} & Yes & 44 & 13.7 & & & & \\
\hline & No & 277 & 86.3 & & & & \\
\hline \multirow{2}{*}{$\begin{array}{l}\text { Enrollment } \\
\text { plan }\end{array}$} & Inner plan & 240 & 82.2 & & & & \\
\hline & outside plan & 52 & 17.8 & & & & \\
\hline \multirow{2}{*}{$\begin{array}{l}\text { Level of } \\
\text { institution }\end{array}$} & 985 & 252 & 33.5 & & & & \\
\hline & 211 & 500 & 65.5 & & & & \\
\hline \multirow{4}{*}{ Grade } & First year & 215 & 28.6 & & & & \\
\hline & Second year & 331 & 44.0 & & & & \\
\hline & Third year & 105 & 13.9 & & & & \\
\hline & Fourth year & 102 & 13.4 & & & & \\
\hline \multirow[t]{2}{*}{ major } & $\begin{array}{l}\text { Social } \\
\text { science }\end{array}$ & 268 & 35.7 & & & & \\
\hline & $\begin{array}{l}\text { Science \& } \\
\text { Engineering }\end{array}$ & 482 & 64.3 & & & & \\
\hline \multirow{5}{*}{$\begin{array}{l}\text { Proportion } \\
\text { of foreign } \\
\text { teachers }\end{array}$} & $<20 \%$ & 187 & 24.9 & & & & \\
\hline & $21 \% \sim 40 \%$ & 105 & 14.0 & & & & \\
\hline & $41 \% \sim 60 \%$ & 154 & 20.5 & & & & \\
\hline & $61 \% \sim 80 \%$ & 209 & 27.9 & & & & \\
\hline & $>81 \%$ & 95 & 12.7 & & & & \\
\hline \multirow{5}{*}{$\begin{array}{l}\text { Proportion } \\
\text { of foreign } \\
\text { language } \\
\text { Instruction } \\
\text { materials }\end{array}$} & $<20 \%$ & 99 & 13.2 & & & & \\
\hline & $21 \% \sim 40 \%$ & 85 & 11.3 & & & & \\
\hline & $41 \% \sim 60 \%$ & 130 & 17.3 & & & & \\
\hline & 61\% 80\% & 192 & 25.6 & & & & \\
\hline & $>81 \%$ & 244 & 32.5 & & & & \\
\hline \multirow{5}{*}{$\begin{array}{l}\text { Proportion } \\
\text { of Chinese } \\
\text { teachers in } \\
\text { foreign } \\
\text { language } \\
\text { Instruction }\end{array}$} & $<20 \%$ & 184 & 24.5 & & & & \\
\hline & $21 \% \sim 40 \%$ & 158 & 21.0 & & & & \\
\hline & $41 \% \sim 60 \%$ & 135 & 18.0 & & & & \\
\hline & $61 \% \sim 80 \%$ & 89 & 11.9 & & & & \\
\hline & $>81 \%$ & 185 & 24.6 & & & & \\
\hline
\end{tabular}




\section{Research Results}

\section{Regression Model}

The statistical software SPSS 16.0 was used to analyze the data, and we found that students' satisfaction was relatively good, with a mean of 3.73 and a standard deviation of 0.702 . The study also investigates the overall satisfaction of students with foreign teachers and Chinese teachers. The statistical findings show that the average level of satisfaction between foreign teachers and Chinese teachers is very close, with mean value of 3.81 and 3.84 respectively (see Table 2).

Table 2 Overall satisfaction level

\begin{tabular}{|l|l|l|l|l|l|}
\hline Variable & Frequency & $\begin{array}{l}\text { Minimum } \\
\text { value }\end{array}$ & $\begin{array}{l}\text { Maximum } \\
\text { value }\end{array}$ & $\begin{array}{l}\text { Mean } \\
\text { value }\end{array}$ & $\begin{array}{l}\text { Standard } \\
\text { Deviation }\end{array}$ \\
\hline Satisfaction & 753 & 1 & 5 & 3.73 & 0.702 \\
\hline Satisfaction with Foreign Teachers & 753 & 1 & 5 & 3.81 & 1.017 \\
\hline Satisfaction with Chinese Teachers & 753 & 1 & 5 & 3.84 & 0.986 \\
\hline
\end{tabular}

The regression analysis was carried out by using the multiple regression models. The dependent variable is the level of student satisfaction, and the independent variables include the individual characteristics of the students, the family background and some variables at the school level. The results show that the model fit index $\mathrm{R}$ square is 0.349 (see Table 3), indicating that $34.9 \%$ of the overall change in student satisfaction can be explained by the variables of the model.

Table 3 Index of Model Fitting

\begin{tabular}{|l|l|l|l|l|}
\hline model & R & R Square & Adjusted R Square & Standard Error of Estimate \\
\hline 1 & $0.591 \mathrm{~b}$ & 0.349 & 0.341 & 0.571 \\
\hline
\end{tabular}

Table 4 Satisfaction Multiple Regression Model and Coefficients

\begin{tabular}{|c|c|c|c|c|c|c|}
\hline \multirow{2}{*}{\multicolumn{2}{|c|}{ model }} & \multicolumn{2}{|c|}{$\begin{array}{l}\text { Unstandardized } \\
\text { Coefficients }\end{array}$} & \multirow{2}{*}{$\begin{array}{l}\text { standardized } \\
\text { Coefficients } \\
\text { Beta value }\end{array}$} & \multirow[t]{2}{*}{$\mathrm{T}$ value } & \multirow[t]{2}{*}{ Sig. } \\
\hline & & B value & Standard error & & & \\
\hline \multirow[t]{14}{*}{1} & (Constant) & 2.483 & 0.104 & & 23.98 & 0.00 \\
\hline & Age & -0.015 & 0.033 & -0.029 & -0.44 & 0.66 \\
\hline & Gender(Male/ Female) & 0.132 & 0.072 & $0.117^{*}$ & 1.83 & 0.07 \\
\hline & Parents' educational level & 0.008 & 0.043 & 0.013 & 0.19 & 0.84 \\
\hline & $\begin{array}{l}\text { Enrollment plan (Internal/ } \\
\text { external) }\end{array}$ & 0.399 & 0.083 & $0.273 * * *$ & 4.82 & 0.00 \\
\hline & $\begin{array}{l}\text { Parents'overseas } \\
\text { experience(yes/no) }\end{array}$ & -0.128 & 0.130 & -0.066 & -0.98 & 0.32 \\
\hline & $\begin{array}{l}\text { major(social science/ } \\
\text { natural science) }\end{array}$ & 0.151 & 0.056 & $0.103 * * *$ & 2.69 & 0.007 \\
\hline & Grade Freshman & 0.600 & 0.085 & $0.384 * * *$ & 7.08 & 0.00 \\
\hline & sophomore & 0.557 & 0.072 & $0.394 * * *$ & 7.76 & 0.00 \\
\hline & Junior & 0.331 & 0.080 & $0.164 * * *$ & 4.14 & 0.00 \\
\hline & $\begin{array}{l}\text { Level of } \\
\text { institution(985/211) }\end{array}$ & -0.348 & 0.062 & $-0.234 * * *$ & -5.58 & 0.00 \\
\hline & $\begin{array}{l}\text { Proportion of foreign } \\
\text { teachers }\end{array}$ & 0.131 & 0.023 & $0.258^{* * *}$ & 5.81 & 0.00 \\
\hline & $\begin{array}{l}\text { Proportion of abroad } \\
\text { Instruction materials }\end{array}$ & 0.030 & 0.023 & 0.059 & 1.27 & 0.20 \\
\hline & $\begin{array}{l}\text { Proportion of Chinese } \\
\text { teachers in foreign } \\
\text { language Instruction }\end{array}$ & 0.124 & 0.017 & $0.267 * * *$ & 7.18 & 0.00 \\
\hline
\end{tabular}

Notes: significance: $*$ is for $\mathrm{p}<0.1, * *$ is for $\mathrm{p}<0.05 . * * *$ is for $\mathrm{p}<0.01$.

The study found that there were significant differences in gender level, male and female students' satisfaction level. And the level of male students was $11.7 \%$, higher than that of girls $(\mathrm{p}<0.1)$. The level of planned student satisfaction is $27.3 \%(\mathrm{p}<0.01)$, or 1.27 times higher than that of unplanned 
students. The satisfaction of humanities student is $10.3 \%$ higher than the science and engineering students. The students in the first, second, and third year were significantly higher than those in the fourth grade students. The 211 college students' satisfaction is $23.4 \%$ higher than 985 college students. The higher the proportion of foreign teachers, the higher is the students' satisfaction.

\section{Conclusion and Recommendations}

Through the above study, we can get some conclusions:

Firstly, satisfaction difference is significant in different individual characteristics of students. The results show that the individual characteristics of students, such as gender, grade, professional, etc. are significantly different in satisfaction. The level of satisfaction of boys is higher than that of girls. The results of this study are consistent with those of Chen (2010) and Zhong (2012).

Secondly, program characteristic variables have a significant impact on student satisfaction. The results also found that some variables of cooperative education programs, such as enrollment plan, the proportion of foreign teachers, the proportion of Chinese teachers in foreign language Instruction, have a significant impact on students' satisfaction.

Thirdly, Institution characteristic variables have a certain impact on satisfaction. The institution level is also a factor that affects students' satisfaction. The results show that 211 college students are more satisfied than 985 college students. A possible reason is that 985 college students are relatively higher in their initial academic performance at the time of enrollment, and their expectations for cooperative Instruction are also higher.

Based on some of the above conclusions, combined with the current situation of cooperative Instruction, we give the following suggestions:

First of all, the level of student satisfaction in cooperative education is close to satisfaction, but there is still a gap between the satisfaction and the expectation. Therefore, cooperative education institutions and programs should be improved by strengthening the quality control of Instruction process to narrow down the gap.

Secondly, cooperative program should strengthen the evaluation and feedback of the curriculum, and we need more cooperation between Chinese and foreign teachers together. It's more difficult for students in the interview process reflecting the low level of foreign teachers, resulting in low GPA, to apply for first-class foreign school to study. In addition, after the test evaluation results are not immediately feedback to the students.

Third, we should pay attention to the personal development of students' attention and academic support. Chinese and foreign cooperation in school Instruction must pay attention to the development of student capacity, especially the development of international competency. They should strengthen the academic support, and provide students with the expressing and performing opportunities both inside and outside the classroom to broader their global perspectives and develop their different kind of capacity i.e. foreign language ability, cooperative capacity in group, and cross-cultural skills.

\section{References}

[1]Binglin Zhong, Haitao Zhou, Huanhuan Xia, The Study of students Service Quality Satisfaction in China-foreign Cooperation Institutions, J.China Higher Education Research(2012)22-26.(in Chinese)

[2]Jun Zhao,A Survey of Undergraduate Instruction Quality Based on Student Satisfaction - A Case Study of Three Universities in Hubei Province, J.Educational Research and Experiment(2013)70-74.(in Chinese)

[3]Heng Chen, A Comparative Analysis of Learning Satisfaction of Chinese and Foreign Cooperative Education Students - A Case Study of "2 + 3" Project of Sino - German Cooperative Education in Z University, J.Education Research Monthly(2010)20-23.(in Chinese)

[4]Wei Bao, The Measurement and Determinants of Student Satisfaction in Higher Education Institution, J.Research in Education Development(2014)22-29+55.(in Chinese) 
[5]Wei Wu, Junyan Luo, A Study on Undergraduates' Satisfaction with Chinese-Foreign Cooperative Program of Independent College, J.Research in Higher Education of Engineering(2016)82-86+148.(in Chinese)

[6]Baojun Fang, Min Chen, Influencing Factors of the Engineering Undergraduate Instruction Quality Based on Students' Satisfaction, J.Journal of Higher Education(2010)79-83.(in Chinese)

[7]Yang Liu, Xiaoyan Li, Mingyi Li, Fansheng Kong, A Study on the Instructional Satisfaction Assessment for Chinese-Foreign Cooperation in Running Schools at University Level, J.Fudan Education Forum(2016)43-48+61.(in Chinese)

[8] NSS, National student survey. http://www.thestudentsurvey.com. 